\title{
Zajedništvo života franjevaca trećoredaca iz samostana Sv. Jeronima i stanovnika Martinšćice na Cresu (1578. - 1618.)*
}

\begin{abstract}
Jedan od triju trećoredskih samostana na Cresu, Sveti Jeronim u Martinšćici, utemeljen je oporukama creske vlastelinke Urse de Colombis i njezina muža Blaža, koji su trećorecima poklonili uvalu u blizini crkve Sv. Martina i posjede u Tihoj (Martinšćici). Gradnja je dovršena oko 1520. godine, a crkva je posvećena 1525. O životu u ovom samostanu od kraja 16. stoljeća svjedoče sačuvane knjige „datja i prijatja“, u rasponu od 1578. do 1920. godine, kada je samostan potpao pod talijansku upravu. U ovom radu korištene su knjige iz razdoblja od 1578. do 1618., koje je objavio fra Anđelko Badurina. Bilješke o prihodima i rashodima otkrivaju mnogo o redovničkoj zajednici u samostanu sv. Jeronima, drugim trećoredskim samostanima i ljudima s Cresa koji su živjeli zajedno s franjevcima trećorecima. Braća iz samostana Sv. Jeronima živjela su u zajedništvu sa stanovnicima Martinšćice, u svakodnevnom vidu međusobne pomoći i duhovne skrbi redovnika nad vjernicima. Svojom specifičnom evangelizacijom, utemeljenom na vrijednostima siromaštva, pokajanja i života s ljudima, usadili su se među puk, rasli zajedno s njime, poučavali ga i postajali dijelom pučke kulture. Činili su to kroz narodu blisku glagoljašku kulturu koja, kao posebnost hrvatskog identiteta, svojom iznimnom vrijednošću obogaćuje i europsku kulturu.
\end{abstract}

Otok Cres bio je jedno od jačih središta franjevaca trećoredaca glagoljaša, $\mathrm{s}$ trima samostanima: Sveta Marija od Anđela na Vijaru kod Osora, utemeljen 1465., Sveti Nikola na Porozini, utemeljen o. 1465. godine, i Sveti Jeronim u Martinšćici. Važnu ulogu u dolasku trećoredaca na otok imali su osorski biskup Antun Palčić (1463. - 1470.), trećoredac fra Matej Mastilić Bošnjak te creski plemići iz obitelji Romeis, Sbara, Bocchina, Colombis, Petris i Draža. ${ }^{1}$ Samostan Svetog Jeronima u Martinšćici utemeljen je oporukom creske vlastelinke Urse de Colombis, rođene de Bocchina, iz 1474. i njezina muža Blaža iz 1479. Zahvaljujući njihovu dari-

Ovaj rad je sufinancirala Hrvatska zaklada za znanost projektom broj HRZZ-IP-11-2013-5106.

1 FARLATI I COLETI 1775: 206-207; IVANČIĆ 1910: 30-31, 161, 233-234, 240-241; A XIII, 17-18. 
vanju i velikom zalaganju fra Mateja Mastilića (Bošnjaka)², redovnici su se u još nedovršeni samostan u uvali Tiha ${ }^{3}$ uselili 1482. godine. Gradnja je dovršena oko 1520. godine, a crkva Sv. Jeronima posvećena je 1525 . godine. ${ }^{4}$

O životu u ovom samostanu svjedoče knjige samostanskih računa „datja i prijatja“ iz razdoblja od 1578. do 1920. godine, koje su sve do 1840. bile pisane glagoljicom. Knjige prihoda i izdataka od 1578. do 1618. objavio je fra Anđelko Badurina. ${ }^{5}$ Izvor donosi niz zanimljivih podataka o funkcioniranju reda, gospodarstvu, pomorstvu i medicini, obrađivanju zemlje i nizu drugih tema - za ovu priliku usredotočila sam se na ono što govori o odnosu redovnika i zajednice u kojoj su živjeli. ${ }^{6}$ Godine 1578. gvardijan fra Juraj Brunčić započeo je bilježiti samostanske prihode i izdatke, a nakon njega su to činili svi gvardijani, neki od njih uredno i vješto, a neki s mnogo grešaka. Te razlike na svoj način svjedoče o duhu trećoredskog redovničkog života. Naime, pojedini među braćom učinili su mnogo za uzlet glagoljaške kulture i duhovnosti, kao npr. Ivan Galić Makedonac, gvardijan 1507. godine, no u samostanu je bilo mjesta i za one koji su jednostavno svjedočili vjeru skromnim pokorničkim življenjem. ${ }^{7}$ Vrijednost je ovog izvora upravo u tome što po prirodi svoga sadržaja govori o malim ljudima koji su iza sebe ostavili svjedočanstvo skromnog trećoredskog života, koji se kroz stoljeća tako malo mijenjao. Naizgled šture bilješke o prihodima i rashodima otkrivaju mnogo o redovničkoj zajednici pedesetak fratara i žakana koji su živjeli u samostanu Sv. Jeronima na kraju 16. i početku 17. stoljeću, o njihovoj samostanskoj svakodnevici te o suživotu s ljudima i prirodom. Među njima je bilo trećoredskih umnika i uglednika, poput fra Jurja Brunčića, fra Šimuna Burutine, fra Mihovila Nižića, fra Bartula Mikuličića, fra Šimuna Hromčića, fra Mikule Baničića, fra Jurja Nižića, fra Marina Meštrovića i drugih, a bilo je i onih redovnika koji bi ostali nepoznati bez ovog skromnog izvora jer je i njihov život bio jednako tako skroman, bez velikih djela, ali s puninom trećoredske duhovnosti. ${ }^{8}$

Franjevci trećoreci živjeli su skromno, gotovo asketski, držeći se ideala siromaštva, rada rukama i molitve. Konstitucije koje je zabilježio fra Šimun Klimantović

\footnotetext{
Opširnije vidi RUNJE 1985: 107-118.

3 Tiha je staro ime za Martinšćicu.

4 BADURINA 1995: 3-4, 14; FARLATI I COLETI 1775: 210; IVANČIĆ 1910: 161, 222-223; A XIX, 23; XXXI, 33-34; XLIX, 54-56.

5 Te se knjige danas čuvaju u Arhivu Provincije franjevaca trećoredaca glagoljaša na Ksaveru u Zagrebu. BADURINA 1984: 164-165, 171; Isti 1995: 5-6.

6 Opširnije vidi JANEKOVIĆ RÖMER 2013: 251-284.

7 BADURINA 1995: 66-69, 131-138, 138-151, 162-167. O školovanju i razlikama u obrazovanju između braće: RUNJE 2001a: 126-137, posebno 131, 161, 176-178; Isti 2003: 79-89.

8 Popis fratara i žakana iz samostana Sv. Jeronima u razdoblju od 1578. do 1618. vidi u: JANEKOVIĆ RÖMER 2013: 276-277.
} 
(Klemenić) u obredniku iz 1509., o samostanskoj disciplini i hijerarhiji, pokorništvu i molitvi, trapljenju tijela, zajedništvu te o duhovnoj i etičkoj razini redovničkog života, slijedili su i trećoreci u Martinšćici. ${ }^{9}$ Izuzevši redovničku dimenziju njihova života, svakodnevicu su provodili u istom ritmu i s istim problemima kao i puk što ih je okruživao. General reda, Antonio de Sillis, koji je početkom 17. stoljeća dva puta posjetio dalmatinsku braću, zabilježio je: „Fratri našega reda, koji su od početka prigrlili pustinjački život, nisu imali donje rublje nego su nosili grubu i prostu tuniku na golo tijelo. Nisu spavali u pernatim krevetima nego na goloj zemlji, na klupama, na gomili drveta ili u najboljem slučaju na prostirci od sijena ili slame... I danas opstoji toliko pohvalna strogost života kod dalmatinske braće našega reda, kao što sam i sam iskusio u vizitacijama ${ }^{\text {“ }}{ }^{10} \mathrm{I}$ u tome su redovnici samostana Sv. Jeronima bili bliski okolnom stanovništvu, za koje vizitator iz 1603. godine kaže da „,̌ivi u oskudici i u krajnjem siromaštvu“. ${ }^{11}$ Knjige „datja i prijatja“ iz Martinšćice svjedoče o skromnom životu - osim blagdanima i drugim iznimnim prilikama, fratri su jeli prema redovničkom pravilu, namirnice koje su sami proizvodili ili kupovali od creskih seljaka. Odijevali su odjeću od vunenog sukna te lanenog i konopljina platna. Od odjevnih predmeta fratara, u knjigama troškova spominju se suknene ili platnene košulje, halje, sivi redovnički habit sa šiljastom kapuljačom (,abit“), ${ }^{12}$ dolama i klobuk te skromne cipele domaće izrade, a tek na jednome mjestu i ,postoli laiski i segalitni“. U trećoredskim Konstitucijama stoji zabrana nošenja donje košulje i spavanja na plahtama, no troškovnik iz Martinšćice, koji spominje plahte, pokrivače, stolnjake i ubruse, svjedoči da je ta strogoća popustila kroz stoljeća. Kupovina sapuna rijetko se spominje, pa se dade zaključiti da su ga redovnici sami pravili. Ni na jednome mjestu ne spominju se kreveti, što je u skladu sa spomenutim izvješćem generala reda Antonija de Sillisa. ${ }^{13}$ Život martinskih trećoredaca odvijao se u ravnoteži između samostanske osame i kontemplacije te doticaja s drugim ljudima, bilo u blizini, bilo u udaljenijim

9 IVANČIĆ 1910: 132; D I: 217-220; KOLUMBIĆ 2001: 194-198; RUNJE 2001a: 134-136; Isti 2001b: 183-193.

10 „Et certe cum fratres nostri Ordinis ab initio vitam eremiticam affectarent, credendum est, eos non habuisse interulas lineas, sed asperam et rudem tunicam super carnem nudam; nec in plumeis lectis cubasse, sed super nudam humum vel super tabulas aut struem lignorum, vel ad plus super stratum foliorum foeni vel palearum... Et hodie tam laudabilis austeritas perseverat adhuc apud Dalmatas nostri Ordinis frates, ut ipsemet ego in visitationibus generalibus fui expertus." IVANČIĆ 1910: 78.

11 Isto: A LXXVIII, 99.

12 O trećoredskoj odjeći vidi IVANČIĆ 1910: 33; D I, 217, 219; BARBERO I FRUGONI 1999: 273; RUNJE 2001a: 42, 47, 79, 113, 115, 119; Isti 2012a: 49-54.

13 BADURINA 1995: 21, 22, 28-30, 38, 39, 43-45, 49, 50, 52, 53, 55, 56, 57, 60, 70, 71, 73, 76, $80,81,85,91,93,103-105,108,111-114,122,123,125,126,129,132,137,138,139,144-146$, $148,151,153-157,166$. 
mjestima. Najbliži su bili s ljudima iz Martinšćice, koja je oko 1603. brojala osamdesetak obitelji. ${ }^{14}$ Knjige ,datja i prijatja“ poimence spominju gotovo 300 laika, pretežno creskih seljaka i ribara, ali i plemića i drugih ljudi s kojima su franjevci komunicirali na otoku i izvan njega. Uz susjede, fratrima su bili osobito bliski najamnici pašnjaka i njiva na njihovim creskim imanjima - naraštaji obitelji Vidović, Dumićević i Kunčić bili su vezani uz samostan. Pomagali su oko poljodjelskih i stočarskih poslova, prijevoza i nabave, unajmljivali samostanske posjede i obrađivali ih, krčili zemlju, ribarili, održavali fratarsku brodicu, pomagali oko gradnji u crkvi i samostanu i obavljali razne popravke. ${ }^{15}$

Fratri su živjeli u zajedništvu s tim ljudima i pomagali im novcem i na druge načine, manifestirajući djelatno ljubav prema bližnjemu; bili su prihvaćeni od seoske zajednice kao njezin neodjeljiv dio. „Datja i prijatja“ samostana Sv. Jeronima iz Martinšćice svjedoče kako su redovnici pomagali svojim susjedima da sagrade i pokriju kuće i zapošljavali ih kao obrađivače, stočare ili sluge u samostanu, njegovali ih i liječili u bolesti. Samostanska cisterna sagrađena na samom kraju 16. stoljeća služila je i seljacima. ${ }^{16} \mathrm{Za}$ sve su poslove seljaci dobivali plaću od fratara, a sluge ili ,junaci“ i hranu, odjeću i obuću. ${ }^{17}$ Žene iz Martinšćice zarađivale su težačkim poslovima na samostanskim imanjima, a također i šivanjem, krpanjem i pranjem fratarske odjeće, posteljine, posoblja, crkvene rubenine i ruha. ${ }^{18}$ I sami fratri znali su raditi zajedno s težacima. U zapisu iz 1589. izrijekom se kaže da su zajedno s težacima nosili kamenje s gromače prilikom krčenja zemlje za nasad vinograda. Rad rukama bio je u tradiciji reda, pa je fra Matej Mastilić, znakovito zvan Ručica, koji je sudjelovao u osnivanju samostana Sv. Jeronima, pred mletačkim vlastima izjavio da se posvećivao molitvi i obredima i danju i noću, ali je isto tako vlastitim rukama popravljao crkve, samostane i cisterne te obrađivao vinograd. Rad rukama bio je jedan od važnih franjevačkih načina evangelizacije - primiti se bilo kakvog poštenog posla zajedno sa seljacima bio je dio njihova zavjeta siromaštva, poniznosti i pokorništva. ${ }^{19}$ „Datja“ spominju i djecu u potrebi,

\footnotetext{
14 IVANČIĆ 1910: A LXXVIII, 99.

15 BADURINA 1995: 10, 13, 16, 19, 20-22, 25, 26, 28, 30, 31, 38, 39, 42, 43, 46, 47, 51, 52, 58, $59,68,70,71,74,78,80,81,84,85,96,90,91,93,94,96,97,100-104,113,116,118,120$, $122,129,153,155,156,159$. Popis stanovnika Martinšćice i drugih laika koji se spominju u knjigama „datja i prijatja“ od 1578. do 1618. vidi u: JANEKOVIĆ RÖMER 2013: 278-281.

16 BADURINA 1995: 58, 72, 77, 137, 154. Fra Petar Runje smatra da su trećoredske zajednice proizašle upravo iz spoja asketskog, pustinjačkog života i milosrdnog rada s bolesnicima. RUNJE 1993: 203.

17 BADURINA 1995: 38, 39, 40, 41, 42, 43, 71, 72, 73, 83, 88, 89, 95, 114, 123, 128, 129, 143 , $145,146,152,153$.

18 Isto: 19, 43, 47, 52, 90, 93, 98, 113.

19 Isto: 53. Usporedi IVANČIĆ 1910: 41-45, 164-166; A XXXVIII, 41-45; RUNJE 2001a: 81, 137, 149, 177. Usporedi PAGLIA 2003: 180; BARBERO I FRUGONI 1999: 271.
} 
kojoj su fratri znali dati nešto novca ili cipele. ${ }^{20}$ Godine 1636. platili su djeci iz susjedstva koja su nabrala 500 puževa, koje su poslali u Veneciju. Prema Badurini, bio je to poklon slikaru Baldassareu d' Anni, koji je naslikao oltarsku sliku samostanske crkve s likovima Sv. Jeronima, Sv. Franje i Sv. Antuna. ${ }^{21}$

Franjevci trećoreci pomagali su svojim sumještanima u pravnim poslovima kada su odlazili u Cres k biskupu, knezu ili sucu, po svojim pravnim i crkvenim poslovima, nosili su i pisma svojih susjeda, dali registrirati njihove oporuke i obavljali druge pravne poslove za njih. U knjigama ,tratne“ navodi se da su fratri išli u Cres ,za cić težakom“. ${ }^{22}$ Sve dok im 1606. nije bilo zabranjeno sastavljati isprave, za svoje su mještane sastavljali oporuke, ugovore i druge isprave. Te i sve druge redovske, samostanske i ine dokumente zapisivali su glagoljicom. ${ }^{23}$ Nažalost, nije poznat inventar samostanske knjižnice, a u troškovniku se tek na rijetkim mjestima spominju knjige, i to samo misali. ${ }^{24}$ Za pretpostaviti je da je i samostan u Martinšćici posjedovao i druge knjige i redovničke zapise slične onima koji se spominju u drugim trećoredskim samostanskim knjižnicama. ${ }^{25}$ Knjige „datja i prijatja“ $i$ isprave koje se u njima spominju već same po sebi svjedoče o glagoljaškoj produkciji u samostanu u korist redovničke zajednice i okolnog stanovništva. ${ }^{26}$

Svećeničkom službom redovnici su na poseban način bili uz svoje susjede - krstili su ih, ispovijedali, pričešćivali, vjenčavali, molili za njih, podjeljivali posljednju pomast, ispraćali s ovoga svijeta i služili mise za njihovu dušu, a puk im je uzvraćao lemozinama, naknadama za vjersku službu, darovima za blagdane i oporučnim legatima koji su upotpunjavali njihove skromne prihode. ${ }^{27}$ Primjerice, Jakov Sokolić je 1606. ustupio samostanu polovinu svoga vinograda „za lubav Božju da rečeni fratri jesu oblijani jovorit (!) dvanaest mis na godišće u njihove crkve... za moju dušu. ${ }^{28} \mathrm{U}$ knjizi „datja i prijatja“ zabilježeno je: „Služismo sv.

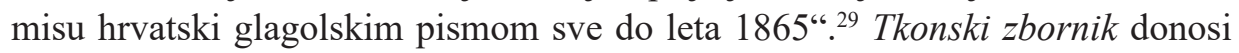
prijepis djela fra Mateja Mastilića Ispovid ku e vsaki krstjanin držan imiti i umiti. Pretpostavlja se da je to djelo bila inkunabula koju je uredio fra Matija Zadranin, a

\footnotetext{
BADURINA 1995: 47, 57.

21 Isti 1984: 170; IVANČIĆ 1910: 225.

22 BADURINA 1995: 78, 82, 88, 92, 110, 114, 155, 167.

23 KLEN 1984: 93, 96; KOŠUTA 1953: 166-167; BEUC 1953: 123; RUNJE 2003a: 204-207.

24 BADURINA 1995: 46, 153; ŠTEFANIĆ 1969: 85; RUNJE 2001a: 163.

25 IVANČIĆ 1910: 126-133, 142, 172; RUNJE 2001c: 57-60; Isti 2001: 162-172.

26 BADURINA 1995: 5.

27 Isto: passim; IVANČIĆ 1910: 95; RUNJE 2003b: 96; Isti 2012b: 58-61.

28 BADURINA 1995: 168; RUNJE 1993: 203-212; Isti 2001: 87, 127-128, 130; IVANČIĆ 1910: 97, 99, 103, 165.

29 BADURINA 1995: 158.
} 
tiskao meštar Pelegrin iz Bolonje. Posvećena je rapskim trgovcima, Žuvanu i Andriji Grimalarki, podrijetlom iz Venecije. Ispit savjesti koji je zabilježio fra Matej na svoj je način svjedočanstvo o životu tadašnjih ljudi, o njihovim poteškoćama i slabostima koje su nastojali savladati uz duhovnu pomoć svojih ispovjednika u sakramentu pokajanja. ${ }^{30}$ Trećoreci glagoljaši služili su se u pastoralnoj službi hrvatskim jezikom, za koji su se borili protiv zabrana mletačke vlasti, zajedno s drugim glagoljašima. ${ }^{31}$ Njihov je samostan bio otvoren svima potrebnima kojima su molitvom, savjetom, poukom i drugim načinima činili duhovna djela milosrđa. Njihova briga za siromašne vjernike očituje se i u tome da su milostinju u crkvi prikupljali samo na velike blagdane, a i tada je bila skromna. ${ }^{32}$ Trećoredski samostani sagrađeni na samotnim mjestima bili su slični pučkim građevinama, oskudno namješteni, namijenjeni siromašnom pokorničkom životu, kao i malene crkve uz njih, nalik kapelicama. ${ }^{33}$ I oprema samostana bila je skromna, katkada i nepotpuna. Događalo se da samostani jedni drugima posuđuju pojedine dijelove ruha i drugog pribora. Primjerice, gvardijan fra Juraj Bručić naložio je 1578. da se posudi manipul samostanu Sv. Marije s Prvića. ${ }^{34}$ Biskup Michele Priuli u vizitaciji iz 1603. zabilježio je da je crkva Sv. Jeronima uređena i da ima sve što treba, ali skromno jer nema gotovo nikakvih prihoda. U crkvi nije bilo dovoljno svijećnjaka, a nedostajalo je i klecalo. I kasnije je u nekoliko navrata zabilježeno da u crkvi Sv. Jeronima nedostaju neke liturgijske knjige i dijelovi crkvene opreme i ruha. O vjernicima je biskup Priuli zabilježio da žive u siromaštvu, ali kršćanski, da obdržavaju sakramente te da ne čine nikakve javne skandale. ${ }^{35}$ Te jednostavne riječi svjedoče o trećoredskom pastoralu u kojem su milosrđe i caritas uvrstili među prioritete te, dijeleći siromaštvo s vjernicima, zadobivali vjerodostojnost, a time i snagu naviještanja Riječi. Njihova askeza nije bila ideal usredotočen samo na njih same, nego prirodan izbor, put posvećenja nedjeljiv od mukotrpnog života ljudi oko njih. Siromaštvo je za njih bilo dio zavjeta koji je jednako vrednovao i vrline pokorništva, poniznosti, milosrđa, poslušnosti, ali i rad - i rukama i umom. ${ }^{36}$ Trećoreci nisu zazirali od vlasništva - smjeli su

30 Tkonski zbornik 2001: 157-163; DAMJANOVIĆ 2002: 249; ŠTEFANIĆ i dr. 1969: 36; RUNJE 2001a: 130.

31 IVANČIĆ 1910: 119-124, 162, 165; RUNJE 2001a: 128.

32 BADURINA 1984: 170

33 IVANČIĆ 1910: 32.

34 BADURINA 1995: 14; VLAHOVIĆ 1990: 74-80.

35 Dokumenti koje je objavio Stjepan Ivančić svjedoče da je i u drugim trećoredskim crkvama 1603. nedostajalo crkvenog pribora, kako kaže vizitator Priuli, zbog siromaštva. IVANČIĆ 1910: A LXXVIII, 95-103, posebno 99; BADURINA 1995: 167-168. Usporedi VLAHOVIĆ 1990: 63-73.

36 O siromaštvu u franjevačkoj teologiji opširnije: ŞENOCAK 2013: 5-26. 
posjedovati nepokretna i pokretna dobra, skromna, ali dovoljna za život. Unatoč pokorništvu i prosjačkom načinu života, trećoredski samostani imali su zemljišne posjede, kuće, stoku, barke i druge izvore prihoda iz kojih su osiguravali svoju egzistenciju i podržavali vjernički puk. Imali su i pravo na pekulij, to jest privatno vlasništvo nad pokretnim dobrima, bilo od zarade, bilo od oporučnih legata, darova ili prošnje. ${ }^{37}$ Bili su djelatni u svijetu, ukorijenjeni u zajednicu vjernika kojoj su služili svojim pastoralom, a koja im je uzvraćala materijalnim i drugim dobrima. Otočka zajednica i trećoredski samostani bili su povezani neraskidivim nitima zajedničkog života, rada i vjere. Time je trećoredsko življeno siromaštvo dobilo snagu najdjelotvornije propovijedi i dalo vjerodostojnost tim ,sijačima vjere“ na narodnom jeziku. Međusobna djela tjelesnog i duhovnog milosrđa afirmirala su vrijednosti franjevačkog posvećenog života, obogaćujući u isto vrijeme duhovnom i vjerskom dimenzijom životnu svakodnevicu vjernika. ${ }^{38}$

Mnogi su ljudi dolazili u posjet redovnicima i ostavljali svoj trag u samostanskim zapisima. Bili su to redovnici iz drugih samostana, ministri reda, prokuratori, vizitatori, predstavnici vlasti, liječnici, prolaznici, ponajčešće susjedi, nadničari, meštri, a nerijetko i Cigani kotlokrpe.$^{39}$ Posebno je bila jaka povezanost martinskih redovnika s drugom trećoredskom braćom. U Martinšćicu su dolazili trećoreci iz creskih samostana Sv. Marije od Anđela na Vijaru kod Osora i Sv. Nikole na Porozini, potom iz Dubašnice i Glavotoka na Krku, iz Zadra i drugih samostana. Knjige prihoda i rashoda spominju pedesetak imena braće trećoredaca koji su dolazili u Martinšćicu kao gosti. Dolazili su ministri, vikari, gvardijani, kancelari, suci, pisari i drugi redovnici. ${ }^{40}$ Sam samostan Sv. Jeronima bio je domaćin kapitula 1604., 1607. i 1618. godine. ${ }^{41}$ Jednako su i fratri iz Martinšćice odlazili u te samostane, najčešće na kapitule, u vizitacije ili na proslave blagdana. Godine 1601. račune samostana Sv. Jeronima pregledao je general talijanske trećoredske družbe, Giovanni Battista Provenzano sa Sicilije, zajedno sa sekretarom Cherubinom Montifreddijem, u samostanu Sv. Marije na Glavotoku. ${ }^{42}$ Franjevci iz Martinšćice svake su godine odlazili u Osor na blagdan i pučku svečanost Sv. Gaudencija, tzv. Gavdenču, 1. lipnja. Sudeći prema troškovniku, ondje su redovnici boravili $3-4$

IVANČIĆ 1910: 95-97, 103; RUNJE 2001a: 137, 148-153, 165; Isti 2003b: 95-98.

38 IVANČIĆ 1910: 32; Usporedi LAMBERTINI 2005: 141-163; PAGLIA 2003: 183-190, 210-211, 224.

39 BADURINA 1995: 9, 32, 45, 48, 78, 81, 97, 101, 154, 158; Isti 1984: 170.

40 Isti 1995: 13, 21, 39, 40, 46, 47, 55, 57, 60, 66, 69, 70, 89, 94, 98, 102, 103-106, 112, 115, 118, 121-123, 125, 126-128, 130, 131, 138, 139, 141, 142, 155, 159, 162; IVANČIĆ 1910: 217-222, 225-227; HILJE 2003: 12-13. Popis vidi u: JANEKOVIĆ RÖMER 2013: 277-278.

41 BADURINA 1995: 110, 122, 167.

42 Isto: 99; IVANČIĆ 1910: 75. O trećoredskim kapitulima, vizitacijama i upravljanju redom opširnije: RUNJE 2001a: 138-143, 176. 
dana u molitvi, obredima i druženju. Božić, Uskrs, Duhove, Tijelovo, Pohođenje Marijino, Sv. Filipa i Jakova, Martinje, Petrovo, Ivanje i druge blagdane često su proslavljali zajedno s osorskim trećorecima, družeći se nakon misnog slavlja uz prigodnu gozbu, vino, razgovor i zabavu. ${ }^{43}$ Često su odlazili u Istru - posebno Krnicu i Plomin, ali i u Labin, Rakalj, Rovinj, Vižinadu i druga mjesta. Ondje su posjećivali trećoredsku subraću ${ }^{44}$ i odlazili u prošnju koja je bila dio njihova redovničkog zavjeta pokore i siromaštva. Prosili su i po Cresu i po drugim „škojima“, novac, žito i druge namirnice. U prošnju su išli svi, žakni i fratri, čak i gvardijani. Detalj iz „datja“ svjedoči o tim putovanjima u duhu Sv. Franje - za razliku od odjeće, redovnici su često kupovali cipele, dva puta godišnje, ${ }^{45}$ što svjedoči o tome da su i pješačenjem živjeli ideal siromaštva - hodajući među siromašnima, jednako siromašni. Redovnička prošnja bila je predmet rasprava još od Franjinih vremena, a u ranom novom vijeku prigovori na nju dobili su novi zamah zbog promijenjenog stava društva prema prosjacima, osobito onima u dobrom zdravlju. Srednjovjekovni sustav socijalne skrbi koji je počivao na vjerom nadahnutom milosrđu postupno je zamijenjen državnim sustavom institucionalizirane skrbi za bolesne, siromašne i marginalizirane. Unatoč tim promjenama, prošnja je tijekom ranog novog vijeka ostala bitan dio trećoredskog franjevačkog propositum vitaetrećoreci nisu prihvatili negativan stav prema prošnji kao dijelu svoga franjevačkog zavjeta siromaštva. ${ }^{46}$ Iako su se pretežno uzdržavali vlastitim dobrima i radom, što duhovnim, što tjelesnim, zadržali su prošnju, ne samo kao dodatni izvor prihoda, nego i kao sredstvo duhovnog rasta, koje ih je trajno spominjalo na obvezu nevezanosti na materijalna dobra. Pješački prosilački pohodi braće trećoredaca po otoku Cresu, Istri i drugim obližnjem krajevima davali su i pastoralne plodove, šireći prostor njihove prisutnosti i utjecaja.

Trećoreci glagoljaši ostavili su mnogo spomena o svome trudu na evangelizaciji puka na hrvatskom jeziku. Gvardijani koji su vodili knjige prihoda i rashoda svoj su red nazivali „Treti red Svetoga Frančiska Provencije Dalmacije i Istrije“, „Treti red s. Franciška Provincie Dalmacie Pokornih“i, neformalno, religiosi ili patres Tertii ordinis, fratres de littera sclava, fratres Illirici, fratres de lingua illirica, fratres de lingua sclavonica ili glagoljaši. ${ }^{47}$ Jezična oznaka de littera sclava za hrvatske trećorece prvi se put javlja upravo u darovnici creskog plemića Blaža de Colombisa, kojom osorskim trećorecima poklanja zemlju u Martinšćici. U ispravi o gradnji trećoredske crkve u Martinšćici spominje se naziv de lingua illirica. ${ }^{48}$ Služeći se

\footnotetext{
43 BADURINA 1995: 37, 43, 44, 45, 46, 47, 48, 51, 52, 57, 100, 125, 129. $91,98,95,99,104,112,117,121,124,129,132,137,141,145,149,152,156,160,165$. 
hrvatskim jezikom i glagoljskim pismom, redovnici trećoreci glagoljaši, nadahnuti duhovnim nasljeđem Svetoga Franje, učinili su siromaštvo i milosrđe svojim društvenim idealom i po tome bili bliski ljudima među kojima su živjeli. Skroman život na bogatoj vjerskoj stazi koju je utabao vedri Poverello bio je sam po sebi propovijed. Vjersko vrednovanje siromaštva nije značilo puko tjelesno trapljenje, nego svjesni odabir askeze kao puta trajne duhovne obnove, evangelizacije puka i radikalne transformacije Crkve u duhovnom smislu. Usađeni među puk, rasli su zajedno s njime, poučavali ga, molili i radili s njime, postajući tako i sami dijelom pučke kulture. ${ }^{49}$ Franjevci trećoreci iz davno prošlih vremena i dalje su nam bliski jer su oni to i htjeli biti, usuđujući se progovoriti jezikom ljudi od krvi i mesa, jezikom „malih“ ljudi. Grafiti i zapisi svećenika, redovnika i žakana očituju tu toplu, blisku ljudskost koja ne skriva svoje osjećaje ni svoju malenost. Fra Toma Matukačić/ Mačukatović, gvardijan samostana 1611. - 1614., čovjek nevješt peru, obnovitelj samostana i crkve, za kojeg znamo da je osobno 1611. nosio jedra na krpanje u Rijeku i izdao čak 100 lira za vino 1613. godine, ${ }^{50}$ zapisao je u knjizi troškova godine 1612.: „To pisah ja, fratar komu e zemla mati, druzi čarvi, bogatstvo grisi, a to po smarti mojoj će bit. To pisah ja..." - jeka Klimantovićevih riječi zabilježenih u Zaglavu svjedoči o težnji za skromnošću i bliskošću s ljudima koja je bila upisana u život trećoredaca. ${ }^{51}$ Upravo su zato oni bili jedan od najučinkovitijih instrumenata kojim se ideal franjevaštva prenosio među laike i usmjeravao njihovu vjeru. Trećoreci su to činili kroz narodu blisku glagoljašku kulturu koja, kao posebnost hrvatskog identiteta, svojom iznimnom vrijednošću obogaćuje i europsku kulturu.

\section{Bibliografija}

BADURINA, Anđelko. 1984. „Datja“ i ,prijatja“ trećoredskih samostana kao izvor za gospodarsku povijest Cresa i Lošinja. U Otočki ljetopis Cres-Lošinj. Izvori za povijest otoka Cresa i Lošinja, sv. 5, ur. Julijano Sokolić, 163-171. Mali Lošinj: Samoupravna interesna zajednica kulture općine Cres-Lošinj.

BADURINA, Anđelko. 1995. Datja i prijatja. Primici i izdaci samostana franjevaca trećoredaca glagoljaša u Martinšćici na Otoku Cresu, knjiga I. 1578-1618. Rijeka: Povijesni arhiv Rijeka.

BADURINA, Anđelko. 2001. Glagoljaštvo trećoredaca općenito. U Iskoni bê slovo. Zbornik radova o glagoljici i glagoljašima zadarskog kraja i crkvi sv. Ivana Krstitelja, ur. Antun Badurina, 50-56. Zagreb: Kršćanska sadašnjost.

\footnotetext{
48 BADURINA 1995: 85, 91; IVANČIĆ 1910: 114; A XIX, 23; A XXXI, 34.

49 RUNJE 2001a: 47, 59, 78.

50 BADURINA 1995: 138-152.

51 Isto: 142; IVANČIĆ 1910: D VI, 225-226.
} 
BARBERO, Alessandro, Chiara FRUGONI. 1999. Medioevo. Storia di voci, raconto di immagini. Roma-Bari: Laterza.

BEUC, Ivan. 1953. Osorska komuna u pravno-povijesnom svjetlu. Vjesnik Državnog arhiva $u$ Rijeci 1: 1-161.

DAMJANOVIĆ, Stjepan. 2002. Slovo iskona. Staroslavenska/starohrvatska čitanka. Zagreb: Matica hrvatska.

FARLATI, Daniele, Jacobo COLETI. 1775. Ecclesia Ragusina cum suffraganeis et ecclesia Rhiziniensis et Catharensis. Illyrici sacri. Sv. 5. Venetiis: Apud Sebastianum Coleti.

HENRYOT, Fabienne. 2012. La quête franciscaine aux XVIIe et XVIIIe siècles: théories et pratiques d'une économie de l'Evangile. U Religione e istituzioni religiose nell'economia europea. 1000-1800, actes de la XLIII Settimana di Studi de la Fondazione Istituto internazionale di storia economica „F. Datini“, Prato, 8-12 mai, 2011., ur. Francesco Ammanati, 293-305. Firenze: Firenze University Press.

HILJE, Emil. 2003. Utemeljenje franjevačkih samostana na zadarskim otocima. Radovi Zavoda za povijesne znanosti HAZU u Zadru 45: 7-19.

Hrvatska književnost srednjega vijeka: od XII. do XVI. stoljeća. 1969. Ur. Vjekoslav Štefanić, Biserka Grabar, Anica Nazor, Marija Pantelić. Pet stoljeća hrvatske književnosti. Knj. 1. Zagreb: Matica hrvatska, Zora.

IVANČIĆ, Stjepan. 1910. Povijestne crte o samostanskom III redu s. o. Franje po Dalmaciji, Kvarneru i Istri i poraba glagolice u istoj redodržavi: sa prilozima. Zadar: Odlikovana tiskarna E. Vitaliani.

JANEKOVIĆ RÖMER, Zdenka. 2013. O životu trećoredaca iz samostana sv. Jeronima u Martinšćici na otoku Cresu (1578. - 1618.). U Bertošin zbornik: Zbornik u čast Miroslava Bertoše, knj. 2, ur. Ivan Jurković, 251-284. Pula, Pazin: Sveučilište Jurja Dobrile u Puli, Državni arhiv u Pazinu.

KLEN, Danilo. 1984. Glagoljicom pisani izvori Lošinja i Cresa. U Otočki ljetopis CresLošinj. Izvori za povijest otoka Cresa i Lošinja, sv. 5, 89-96. Mali Lošinj: Samoupravna interesna zajednica kulture općine Cres-Lošinj.

KOLUMBIĆ, Nikica. 2001. Konstitucije franjevaca trećoredaca kao književno-jezični hrvatski spomenik. U Iskoni bê slovo. Zbornik radova o glagoljici i glagoljašima zadarskog kraja i crkvi sv. Ivana Krstitelja, ur. Antun Badurina, 194-198. Zagreb: Kršćanska sadašnjost.

KOŠUTA, Leo. 1953. Glagoljski tekstovi u arhivu osorske općine. Vjesnik Državnog arhiva u Rijeci 1: 163-218.

LAMBERTINI, Roberto. 2005. Poverty and Power: Franciscans in Later Medieval Political Thought. U Moral Philosophy on the Treshold of Modernity, ur. Jill Kraye, Risto Saarinen [The New Synthese Historical Library vol. 57], 141-163. Dordrecht: Kluwer Academic.

NEŽIĆ, Dragutin. 2000. Iz istarske crkvene prošlosti. Pazin: Josip Turčinović, Pazinski kolegij - klasična gimnazija.

PAGLIA, Vincenzo. 2003. Storia dei poveri in Occidente. Indigenza e carità. Milano: Biblioteca Universale Rizzoli. 
RUNJE, Petar. 1985. Novi prilozi za život o. Mateja Bošnjaka-Mastilića, franjevca trećoreca (o. 1430-1525). Croatica Christiana Periodica 9/16: 107-118.

RUNJE, Petar. 1993. L'attivita pastorale dei francescani del Terz'ordine regolare nel medio evo in Croazia. U Terziari francescani in età moderna: antico e nuovo mondo. Atti del 6. Convegno di studi francescani, Milano, 22-24 settembre 1992., ur. Lino Temperini [Analecta Tertii Ordinis Regularis Sancti Francisci 61], 203-212. Roma: Franciscanum.

RUNJE, Petar. 2001a. Pokornički pokret i franjevci trećoredci glagoljaši: (13. - 16. st.). Zagreb: Provincijalat franjevaca trećoredaca, Kršćanska sadašnjost.

RUNJE, Petar. 2001b. Fra Šimun Klimantović i konstitucije 1492. U Iskoni bê slovo. Zbornik radova o glagoljici i glagoljašima zadarskog kraja i crkvi sv. Ivana Krstitelja, ur. Antun Badurina, 183-193. Zagreb: Kršćanska sadašnjost.

RUNJE, Petar. 2001c. O knjigama glagoljaša u drugoj polovici 14. i u 15. stoljeću u Zadarskoj nadbiskupiji. U Iskoni bê slovo. Zbornik radova o glagoljici i glagoljašima zadarskog kraja i crkvi sv. Ivana Krstitelja, ur. Antun Badurina, 57-67. Zagreb: Kršćanska sadašnjost.

RUNJE, Petar. 2003a. Franjevci trećoredci kao javni bilježnici u 16. i 17. stoljeću. Senjski zbornik 30: 201-210.

RUNJE, Petar. 2003b. Školovanje glagoljaša. Ogulin: Matica hrvatska, Ogranak.

RUNJE, Petar. 2012a. Odijelo franjevaca trećoredaca u srednjem vijeku. U Prema izvorima II. Rasprave i članci o hrvatskim franjevcima trećoredcima glagoljašima, ur. Tomislav Galović [Krčki zbornik, sv. 68. Posebno izdanje, sv. 61. Bibliotheka Novaja i vethaja, knj. 9.], 49-54. Krk, Zagreb: Povijesno društvo otoka Krka, Provincijalat franjevaca trećoredaca glagoljaša.

RUNJE, Petar. 2012b. Pastoralna djelatnost trećoredaca u srednjem vijeku. U Prema izvorima II. Rasprave i članci o hrvatskim franjevcima trećoredcima glagoljašima, ur. Tomislav Galović [Krčki zbornik, sv. 68. Posebno izdanje, sv. 61. Bibliotheka Novaja i vethaja, knj. 9.], 55-61. Krk, Zagreb: Povijesno društvo otoka Krka, Provincijalat franjevaca trećoredaca glagoljaša.

ŞENOCAK, Neslihan. 2013. The Making of Franciscan Poverty. Revue Mabillon, revue internationale d'histoire et de littérature religieuses n. s. 24: 5-26.

ŠTEFANIĆ, Vjekoslav. 1969. Glagoljski rukopisi Jugoslavenske akademije. Sv. 1. Zagreb: JAZU.

Tkonski zbornik. 2001. Ur. Slavomir Sambunjak. Tkon: Općina Tkon.

VLAHOVIĆ, Josip. 1990. Inventari crkve i samostana sv. Franje u Cresu u 16. stoljeću. Croatica Christiana Periodica 14/26: 62-82. 


\section{The Communion of the Life of Franciscan Tertiaries from the Monastery of St. Jerome and the Inhabitants of Martinšćica on the Island of Cres $(1578-1618)$}

One of the three monasteries of Tertiaries on the island of Cres, St. Jerome in Martinšćica, was founded in the testament of the local noblewoman Ursa de Colombis, née de Bocchina (1474), and her husband Blaž (1479). Bishop Antun Palčić and a Franciscan Tertiary Matej Mastilić Bošnjak played an important role in the foundation of the monastery. In 1482, monks moved into the still unfinished monastery in the bay of Tiha. The building activities were completed around 1520, and the church of St. Jerome was consecrated in 1525. Preserved ledgers of datja and prijatja (tributes and revenues) from 1578 to 1920, when the monastery came under Italian administration, provide an insight into the everyday life in this monastery. This paper uses ledgers from the period between 1578 and 1618 , as published by A. Badurina. The seemingly bleak notes about revenues and expenses prove to be rather revealing with regard to the monastic community in the monastery of St. Jerome, other monasteries of Tertiaries and the people of Cres who lived together with the Franciscans of the Third Order. In addition to the information pertaining to the Franciscans of the Third Order and the economic history of the island of Cres and adjacent areas, the ledgers provide many other interesting details. They contain information about diet, production, medicine, clothes, furniture and kitchenware, tools, animals, ships, fishing, about neighbours, servants, friends and superiors, about encounters and travels, vintage and harvest, about shortage and holiday feasts, about church, rituals, furnishings and robes, as well as about extending and improving the estate. These sources are particularly valuable since, given the nature of their content, they provide information about ordinary people who left a testimony of a humble life of Tertiary Franciscans, which changed so little throughout centuries. The ledgers paint a picture of the everyday monastic life, of the common life of the Tertiaries with the inhabitants of Martinšćica, the island's peasants and townspeople, aristocrats and authorities and other brethren of the Order. The ledgers of datja and prijatja mention approximately 100 tertiaries and žakans (deacons) from the monastery in Martinšćica and other monasteries, as well as around 300 lay persons, mostly peasants from Cres, hired labourers working on monastic estates, servants, neighbours, but also nobles from Cres. The brethren of St. Jerome lived in communion with the inhabitants of Martinšcica, providing mutual everyday assistance and religious care for the faithful. They led a modest life, almost ascetic, and clung to the ideal of poverty, manual labour and prayer. Apart from the monastic dimension of their lives, they spent their everyday lives in the same rhythm and with the same problems as the people in the surrounding community. The Glagolitic Franciscan Tertiaries 
lived and worked with these people, helped and received help from them, and supported them spiritually with their priestly office. Due to their specific form of evangelisation based on the values of poverty, penitence and life among the people, the Tertiaries implanted themselves among the common people, grew with them, educated them and became a part of the popular culture. They did this in the context of the Glagolitic culture which was familiar to the people and which, as a specific feature of Croatian identity, enriches the European culture with its exceptional value.

Keywords: Franciscan friars of the Third Order Regular, Glagolitism, everyday life, history of the island of Cres.

Ključne riječi: franjevci trećoreci, glagoljaštvo, svakodnevni život, povijest otoka Cresa.

Zdenka Janeković Römer Zavod za povijesne znanosti HAZU u Dubrovniku HR-20000 Dubrovnik, Lapadska obala 6 zdenka.janekovic-roemer@zg.ht.hr 


\section{FILOZOFSKI FAKULTET SVEUČILIŠTA U ZAGREBU \\ ZAVOD ZA HRVATSKU POVIJEST \\ INSTITUTE OF CROATIAN HISTORY \\ INSTITUT FÜR KROATISCHE GESCHICHTE}

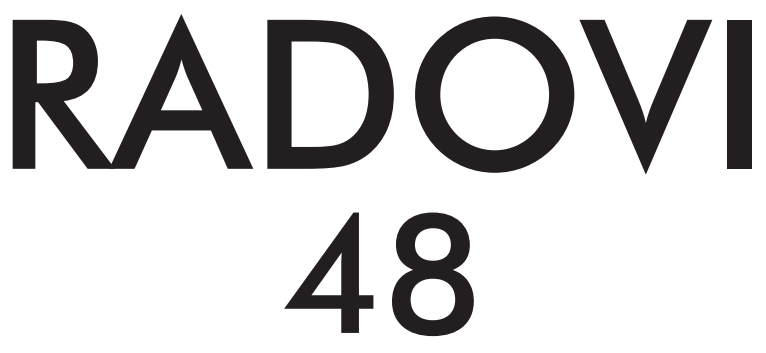

ZAVOD ZA HRVATSKU POVIJEST

FILOZOFSKOGA FAKULTETA SVEUČILIŠTA U ZAGREBU

\section{FF press}

ZAGREB 2016. 


\title{
RADOVI ZAVODA ZA HRVATSKU POVIJEST FILOZOFSKOGA FAKULTETA SVEUČILIŠTA U ZAGREBU \\ Knjiga 48
}

\author{
Izdavač / Publisher \\ Zavod za hrvatsku povijest \\ Filozofskoga fakulteta Sveučilišta u Zagrebu \\ FF-press \\ Za izdavača / For Publisher \\ Željko Holjevac \\ Glavni urednik / Editor-in-Chief \\ Hrvoje Gračanin \\ Izvršna urednica / Executive Editor \\ Inga Vilogorac Brčić \\ Uredništvo / Editorial Board
}

Bruna Kuntić-Makvić (stara povijest/ancient history), Zrinka Nikolić Jakus (srednji vijek/ medieval history), Hrvoje Petrić (rani novi vijek/early modern history), Željko Holjevac (moderna povijest/modern history), Tvrtko Jakovina (suvremena povijest/contemporary history),

Silvija Pisk (mikrohistorija i zavičajna povijest/microhistory and local history),

Zrinka Blažević (teorija i metodologija povijesti/theory and methodology of history)

Međunarodno uredničko vijeće / International Editorial Council

Denis Alimov (Sankt Peterburg), Živko Andrijašević (Nikšić), Csaba Békés (Budapest), Rajko Bratož (Ljubljana), Snježana Buzov (Columbus, Ohio), Svetlozar Eldarov (Sofija), Toni Filiposki (Skopje), Aleksandar Fotić (Beograd), Vladan Gavrilović (Novi Sad), Alojz Ivanišević (Wien),

Egidio Ivetić (Padova), Husnija Kamberović (Sarajevo), Karl Kaser (Graz),

Irina Ognyanova (Sofija), Géza Pálffy (Budapest), Ioan-Aurel Pop (Cluj),

Nade Proeva (Skopje), Alexios Savvides (Kalamata), Vlada Stanković (Beograd), Ludwig Steindorff (Kiel), Peter Štih (Ljubljana)

\section{Izvršna urednica za tuzemnu i inozemnu razmjenu / Executive Editor for Publications Exchange \\ Kristina Milković}

Tajnik uredništva / Editorial Board Assistant
Dejan Zadro

Adresa uredništva/Editorial Board address

Zavod za hrvatsku povijest, Filozofski fakultet Zagreb, Ivana Lučića 3, HR-10 000, Zagreb

Tel. ++385 (0)1 6120 150, 6120 158, faks ++385 (0)1 6156879

Časopis izlazi jedanput godišnje / The Journal is published once a year

Časopis je u digitalnom obliku dostupan na / The Journal in digital form is accessible at Portal znanstvenih časopisa Republike Hrvatske „Hrčak“ http://hrcak.srce.hr/radovi-zhp

Financijska potpora za tisak časopisa / The Journal is published with the support by

Ministarstvo znanosti, obrazovanja i športa Republike Hrvatske

Časopis je indeksiran u sljedećim bazama / The Journal is indexed in the following databases:

Directory of Open Access Journals, EBSCO, SCOPUS, ERIH PLUS, Emerging Sources Citation Index - Web of Science 


\section{Naslovna stranica}

Iva Mandić

Grafičko oblikovanje i računalni slog

Marko Maraković

\section{Lektura}

Samanta Paronić (hrvatski / Croatian)

Dražen Nemet (engleski / English)

Tisak

Tiskara Zelina d.d., Sveti Ivan Zelina

Naklada

250 primjeraka

Časopis je u digitalnom obliku dostupan na Portalu znanstvenih časopisa Republike Hrvatske ,Hrčak" http://hrcak.srce.hr/radovi-zhp

The Journal is accessible in digital form at the Hrcak - Portal of scientific journals of Croatia http://hrcak.srce.hr/radovi-zhp 


\section{RADOVI 48}

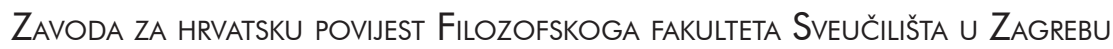

